\title{
Vertical Co-operation in Creative Micro-Enterprises: A Case Study of Textile Crafts of Matiari District, Pakistan
}

\author{
Mohsin Shafi, Yongzhong Yang *, Zobi Khan and Aixian Yu \\ Business School, Sichuan University, Chengdu 610065, China; 2016521081013@stu.scu.edu.cn (M.S.); \\ 2017521080109@stu.scu.edu.cn (Z.K.); yuaixian@stu.scu.edu.cn (A.Y.) \\ * Correspondence: yangyongzhong@scu.edu.cn
}

Received: 30 December 2018; Accepted: 30 January 2019; Published: 12 February 2019

check for updates

\begin{abstract}
Despite their cultural and economic importance, creative micro-enterprises have received very little attention from academia research, especially with respect to vertical co-operation-customers and suppliers-and innovation. This study aims to fill the literature gap by studying how vertical co-operation improves the performance of micro-enterprises in textile crafts through innovation. A questionnaire was used to collect data from creative micro-enterprises in the textile craft sector operating in the Matiari District of Pakistan. To test the construct validity of the research, Exploratory Factor Analysis (EFA) and Confirmatory Factor Analysis (CFA) were conducted, and to examine the hypotheses, the bootstrap re-sampling method was used with the SPSS PROCESS macro developed by Hayes. The findings of this study indicate that vertical co-operation positively and significantly affects the innovation and performance of creative micro-enterprises in textile crafts. In addition, we find that innovation plays a significant mediating role between vertical co-operation and performance. Furthermore, contrary to some studies, we empirically provide evidence regarding innovation in craft in terms of product development (design, size, shape, color, etc.), improvement in quality, and replacement/modification of tools.
\end{abstract}

Keywords: creative micro-enterprise; textile crafts; vertical co-operation; innovation; performance

\section{Introduction}

Creative industries are increasingly being considered as new tools for sustainable development. These industries have been widely acknowledged for income and job creation [1-7]. Creative micro-enterprises (which include craft) are an important part of creative industries, primarily because most firms are operated by a small number of people (often less than 10 employees [8]) and are the predominant firm type [9]. In this era of globalization and industrialization, small creative firms face numerous hurdles, which include resource constraints, market competition, and short product lifecycles, among others. The introduction of machine-made substitutes has made the situation worse by offering a wide variety of products that are much cheaper $[6,10,11]$. Innovation is an essential part of these enterprises, as they help the firms to adopt new strategies and offer new services/products in an attempt to survive in the market [12]. Furthermore, traditional craft products are often old-fashioned and do not attract consumers, thus prompting the need to adopt innovation, as suggested by many scholars [6,13].

Innovation has also been linked to knowledge sources used to generate ideas. A significant number of studies has indicated a positive link between external co-operation and innovation [14-19]. Since creative micro-enterprises in the craft sector do not possess sufficient resources to successfully embrace innovation, they engage in co-operation, which could create opportunities for development $[9,20-23]$. 
This co-operation has caught the attention of academia and has been studied from various aspects, such as collaboration, social network, alliance, innovation co-operation, inter-firm networks, open innovation, etc. [17-20,22,24-26]. However, in the specific context of creative micro-enterprises, particularly in the craft sector, very few studies exist. For example, Duarte Alonso and Bressan [26] examined the collaboration between micro firms in Italy that were involved in terracotta art, Jaouen and Gundolf [27] examined specific patterns of strategic alliance among micro firms in France, Torres [25] examined marketing networks among craft enterprises in Ireland, and Gundolf, Jaouen, and Gast [9] recently examined the motives behind strategic alliances between micro creative firms in France. However, none of these studies have examined the effects of vertical co-operation (via innovation) on performance. Additionally, several scholars request investigations into the extent to which micro-entrepreneurs seek innovation through cooperation [16,26]. In addition, despite the importance of innovation in micro-enterprises, some studies have raised concerns, because the craft industry quintessentially involves the use of traditional skills and knowledge [26,28]. The literature regarding innovation in crafts is also scarce. Furthermore, most of these studies are qualitative in nature $[25,26]$, and to the best of our knowledge, no quantitative study has been conducted in this respect. Moreover, no study exists in Pakistan that has studied co-operation and/or innovation in the craft sector. This justifies the need to examine the proposed relationship in order to fill the identified literature gap.

Further, in this study, we have focused on vertical co-operation-customers and suppliers, the reasons for the same being as follows: First, the social network of craft micro-entrepreneurs is usually not very large. Second, it has been reported that vertical co-operative partners are the most preferred partners for innovation [29,30], especially in micro-enterprises $[14,15,31,32]$. Third, vertical co-operation is aimed at radical innovation (small changes) [33], as handicrafts involve traditional knowledge and skills, which micro-entrepreneurs intend to keep intact [34]. Fourth, due to lack of market and consumer information, craft micro-entrepreneurs with the skills to make/modify their products to satisfy consumers' needs, are actually unaware of market and customer demands [35]. Thus, an improved understanding of cooperation and innovation at the producer level is of great importance in poverty reduction, economic growth, and employment generation [36]. Further, identification of factors that affects the performance of craft micro-enterprises will be very useful not for only practitioners but also for policymakers, who can clarify what needs to be done to maximize opportunities for micro-enterprises in the context of Pakistani craft.

Through this study, we seek to contribute to existing knowledge on creative micro-enterprises in the handicraft sector by providing a deeper insight on how they innovate their products through external cooperation. Since the decision to develop an external relationship and use external resources is a strategic one, this study hopes to contribute to the strategic management literature as well. In terms of practical implication, this study seeks to provide practitioners with a deeper grasp of how to manage their external counterparts in the best possible way in order to ensure successful innovation. Micro-entrepreneurs will also be provided with insights on how to maintain their external relationships and how such associations affect innovation. With regard to methodological implications, we provide insight on how innovation mediates between vertical cooperation and performance. Finally, the paper suggests areas for future research, which will be a guide to the relevant academic community.

The structure of the paper is as follows: The following section provides a detailed description of the research context and outlines the theoretical background. Section 3 describes the conceptual framework and hypotheses development. In the Section 4, detailed information about the methodology used in this study (including sampling details, statistical analysis technique, etc.) is given. Section 5 presents the results of our data analysis. Section 6 is devoted to the discussion of findings of the study. Conclusion, implications, and limitations of our study are presented in the final section. 


\section{Literature Review}

\subsection{Pakistani Handicrafts}

Pakistan is blessed with a very rich history and culture of handicrafts [37]. Craft activities are distributed extensively throughout the country. There are several types of handicrafts found in Pakistan such as metal, pottery, wood carving, jewelry, textile, leather, carpet, etc. The Pakistani handicraft industry significantly contributes to economic and employment generation and also helps in the economic and social sustainability of the country. Handicraft businesses are vital to the Pakistani economy as they represent the main source of income for many families, especially in rural areas.

Acknowledging that handicraft micro-enterprises are not a homogeneous group and each sector within this industry differs from others; hence, we have focused on a specific sector, i.e., textile craft. Particularly, the choice of the textile sector in Pakistan is based on its significant economic contribution and a large number of producers involved in this sector. Furthermore, the artisans involved in this sector have much interaction with the customers as well as the end users.

The textile crafts of Matiari District, Pakistan, are very famous for their designs, colors, and variety. These textile craft products are sold to various segments of customers through local shops and export. The textile crafts produced in Matiari District of Pakistan are famous and dominated for production of traditional Ajrak (block printed shawl), Sindhi Topi (handwoven cap), and handwoven cloths, among others. Textile craft production employs a significant number of poor rural peoples. These textile crafts are very popular not only in Pakistan but also abroad and are in daily use of local peoples regardless of income level. Most of the artisan producing textile crafts are working individually or at a smaller level, most probably micro-enterprise level. Thus, these businesses find it difficult to compete with low-priced imported substitute products; therefore, their market share is shrinking [6]. In addition, there had been numerous micro-enterprises operating in the area employing thousands of craftspeople, but the number diminished rapidly; the resources constraints and lack of innovation are usually considered as the reasons behind such failure [38]. Moreover, research conducted among handicraft firms in Pakistan also underlines similar shortcomings among micro firms [6]. Thus, these micro-enterprises need to improve their product designs to meet consumers' demand. In order to successfully innovate and exploit products in the market, the detailed knowledge and information about market and consumers are necessary.

Promising opportunities in the handicraft value chain include cooperation and innovation. Keeping in mind the needs and desires of the target customers as well as the current fashion and design trends, improvements in products can facilitate innovation through co-operation. This will enable micro-enterprises to innovate their products to meet consumer demands better.

\subsection{Innovation and Vertical Co-Operation in Micro-Enterprises}

In a highly competitive and dynamic environment, the micro-enterprises have to adopt innovation in order to expand, survive and create a smart future $[14,15,39,40]$. Similarly, in the context of creative micro-enterprises in craft sector, the innovation is also important, and the micro-entrepreneurs have to offer more innovative, unique and high-quality products [13] in order to meet the needs of consumers for their survival in the market [12]. Moreover, in order to satisfy the needs and desires of the customers, it is necessary to customize the products according to the users' needs [41]. Conventionally, the firms develop new products through their internal capabilities and knowledge base [42]. However, in the case of creative micro-enterprises, due to lack of resources, these businesses are unable to innovate their products merely based on their internal knowledge base and capabilities [25]. These firms engage in co-operation $[9,21]$ in order to cover such resources shortage and develop new ideas [22].

In addition, Morris et al. [43] (p. 38) contends that, "compared to the medium and large-sized counterparts, small ventures are more vulnerable to environmental forces," these firms face resources constraints, changing customer demands, and competition from related substitute products [6]. Consequently, several studies suggest that external co-operation can help these firms to improve 
their performance $[9,25,44]$. Moreover, cooperation helps enterprises to develop their capability to compete with competitors and provide access to external resources [44].

The co-operation can be vertical, horizontal, or institutional; however, considering the nature of creative micro-entrepreneurs in the craft sector, we have focused particularly on vertical co-operation. Moreover, it has been reported that the vertical relationships among customers, suppliers are important to enhance innovation [23,32], while horizontal co-operation has an adverse effect on innovative capacity [31].

External knowledge sources, particularly vertical co-operative partners, are important sources to improve products $[14,15,45,46]$. Furthermore, these external sources can also help to reduce risk, cost and time related to the development of products and helps to improve the quality of products as well. Thus, providing a competitive advantage to the firms. The relevant literature further indicates that high product quality, diversity and innovative approach of producers are important factors for successful cultural industries in Los Angeles [47]. The study of Torres [25], focused on network alliance in craft enterprises in Ireland, indicates that cooperative alliance is necessary for the survival, growth, and competitiveness. The author concluded that as the craft enterprises have limited opportunities to make an impact on the market place due to the shortage of resources and expertise. Thus, external co-operation is important for such enterprises in order to achieve a competitive advantage in the market on a low-cost basis $[9,25,26]$.

\section{Conceptual Framework and Hypotheses Development}

\subsection{Relationship between Vertical Co-Operation and Innovation}

Harabi [23] highlighted that vertical co-operation enable firms to enhance the capabilities and help to reduce uncertainties about market demand. Similarly, Löfqvist [48] studied the motivation for innovation in small firms and demonstrated that small firms can take benefits through interaction with customers during the innovation process. Furthermore, according to Von Hippel [49], the independent innovators (termed here as micro-entrepreneurs) only possess embodied knowledge and are less likely to innovate as compared with vertical partners such as customers and suppliers. In addition, establishing vertical co-operation also help to share risk and uncertainty. Several authors have acknowledged the importance of vertical partners because the innovation is not merely done by the producer but involves certain partners [50]. Further, Ferraris, Santoro, and Bresciani [19] concluded that external knowledge positively and significantly affects the performance. Additionally, Goldsby, Kreiser, Kuratko, Bishop, Kreiser, and Hornsby [39] also concluded that innovation is one of the key organizational outcomes associated with competitiveness.

In addition, the interaction with vertical co-operative partners allows enterprises to learn and acquire new opportunities. As the study of Tether [51], indicates that the value chain cooperation enables sharing of new knowledge and information between these partners, whereas, the feedback allows improvement of the innovation process.

Textile crafts are also linked towards fashion industry; hence, many consumers may not like the repetitive and old-fashioned designs [25], rather a little touch of modernity without killing the traditional motif attracts the consumers. Furthermore, Tomlinson [15] found that in textiles, the higher level of supplier's cooperation has a significant effect on innovation, further supplier cooperation for the use of different fabrics and fibers enhance product improvement levels. Vertical knowledge flow is a key factor that helps the producer to make decisions to innovate [30]. Thus, we propose the following hypothesis:

H1: Vertical co-operation has a significant effect on innovation.

\subsection{Relationship between Innovation and Performance}

Numerous studies exist that indicate a link between innovation and firm performance in small firms (such as [12,14,52,53]). Further, Rajapathirana, and Hui [53] concluded that effective management 
of innovation could help to deliver more effective innovation outcomes to generate better performance. Similarly, in the context of craft micro-enterprises, it has been argued that in order to enable enterprises to survive, compete, and grow, innovation is one of the key factors to be considered $[12,13,54]$. Furthermore, the enterprises having a variety of product assortments are likely to succeed in the market [13].

Moreover, co-operation also plays a key role for micro-enterprises in innovation and improving their performance [55]. For instance, the study of Engel et al. [56] focused on innovation and its impact on the growth of small firms in craft industries in Germany, concluded that innovation has a positive impact on sales growth of small firms. It has also been reported that innovation in handicrafts is aimed to decrease the cost, enhance production, profit, and sales [57]. Consequently, an increased level of innovativeness in the micro-enterprises could be positively related to higher sales and growth. Thus, we propose the following hypothesis:

H2: Innovation has a significant effect on the performance

\subsection{Relationship between Vertical Co-Operation and Performance}

Vertical co-operation enables craft micro-entrepreneurs to acquire the latest information about the market and consumer preferences. Usually, the micro-entrepreneurs in the craft sector are unaware about the synergistic effects of co-operation. Vertical co-operation with customers and suppliers enable enterprises to access low-cost information and resources about market, consumers, and credit for capital, training, technical services, etc. By delivering information and technical assistance, customers and suppliers can reduce delivery costs. In addition, in order to respond to customer's inconsistent demands, micro-entrepreneurs apply creativity and information obtained from the market. The study of Radicic and Pugh [58] indicates that small firms mostly undertake user innovation and customer involvement has a positive impact on innovation performance in such firms. In addition, Molina et al. [59] also argues that in order to make the craft business profitable, it is necessary to assess the market and adapt to the needs of consumers.

This intense social interaction increases the transfer of tacit knowledge which is usually time-consuming [60,61]. Further, the intangibility nature of this knowledge makes it rare, valuable and difficult for competitors to imitate hence offering the craft micro-enterprises and advantage in the market through its development of new products [62,63]. Moreover, it has been reported that the vertical co-operation with external agents directly affects the firm's performance [64]. Thus, we propose the following hypothesis:

H3: Vertical co-operation has a significant effect on the performance

\subsection{Innovation as a Mediator between Vertical Co-Operation and Performance}

The external co-operation enables enterprises to improve their capabilities by acquiring new knowledge [65]. For instance, Tu, Hwang, and Wong [14], conducted a study on micro-enterprises based in Taiwan and found that co-operation with suppliers has a positive effect on innovation. In addition, a good relationship between micro-enterprises and customers may create customers' loyalty, ensure continuous demand and feedback from customers [66], and help to improve the performance of micro-enterprises. Accordingly, both vertical partners are important to exploit innovation successfully.

Further, the study of Saunila et al. [67] indicates that external cooperation significantly enhances innovation performance. The vertical co-operation enables enterprises to bring new knowledge and information in order to extend the innovative success [67]. In addition, vertical cooperation enables enterprises to get better access to knowledge and resources to exploit innovation in the market successfully [68]. Therefore, we propose the following hypothesis:

H4: Innovation significantly mediates the effect of vertical co-operation on performance 
The literature review highlighted the importance of vertical cooperation and its effect on innovation and firm performance. Based on the above literature, the research model is proposed in Figure 1.

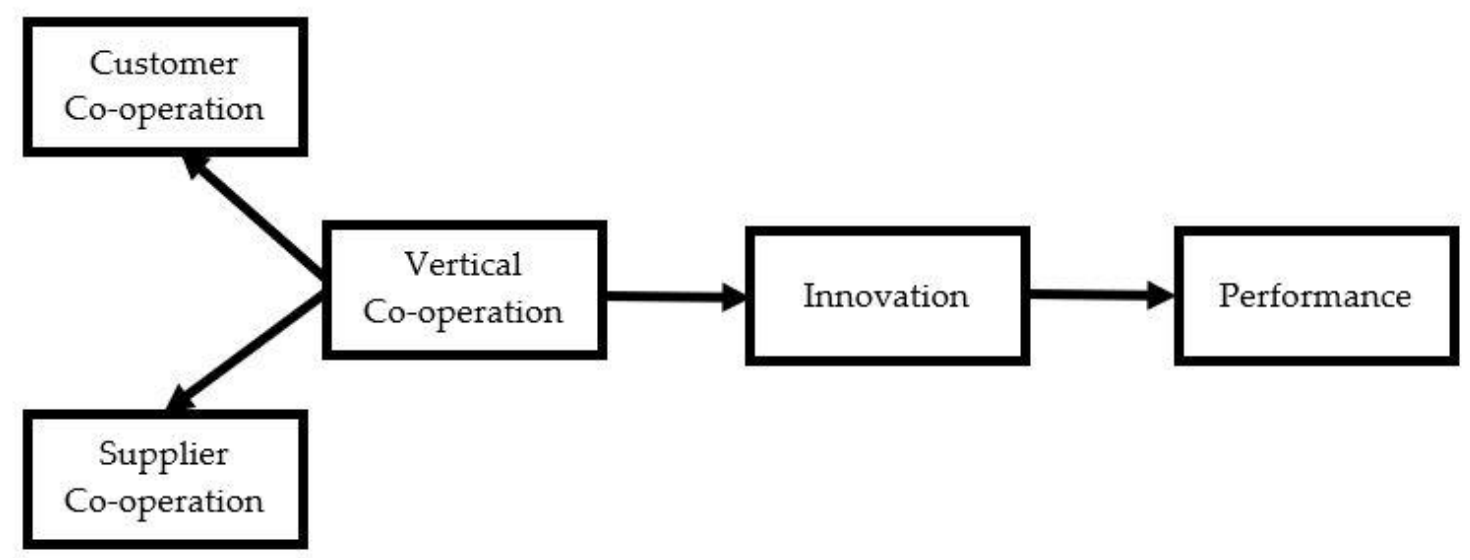

Figure 1. Research model.

\section{Research Methodology}

\subsection{Sample Collection}

The target population identified for gathering information regarding this concern is textile craft micro-enterprises operating in District Matiari, because these textile crafts are very famous all over Pakistan and even abroad. The primary focus of the research is to measure the impact of vertical cooperation upon performance via innovation within the textile crafts of Matiari District. The research, therefore, drew upon a sample of textile craft micro-enterprises. A quantitative methodological approach was employed using questionnaires to gather data. Considering the small size and educational level, it was decided to collect data through the personal interview in order to avoid misinterpretation of constructs.

In this study, the SPSS macro PROCESS developed by Hayes [69] was used to test the effect of vertical co-operation (independent variable) on innovation (mediating variable) and firm performance (outcome variable) including the mediation analysis through bootstrap re-sampling. The quantitative method was selected in accordance with the objectives of the study; moreover, various studies on co-operation have also adopted a similar methodology $[14,15,19,70]$.

A total of 94 complete and valid questionnaires were collected. The sample comprised of $37 \%$ male and $63 \%$ female micro-entrepreneurs. Additionally, the sample covered a broad age sets from 26 to above 50 years old, and the age distribution was relatively concentrated on respondents within 41-50 years old (aged 26-30, 4.3\%; aged 31-35, 14.9\%; aged 36-40, 17.0\%; aged 41-50, 62.8\%; and aged 50 and above, $1.1 \%)$.

\subsection{Measurement}

To measure the vertical co-operation, the scale provided by Tomlinson [15] was adopted. Specifically, the co-operation with customers and suppliers was measured with the following items: "I co-operate with vertical partners to improve products," "I co-operate with vertical partners to manufacture new product designs," "Vertical partners and I exchange information/experience," "I co-operate with vertical partners for technological up-gradation," "I co-operate with vertical partners to improve the quality of inputs," and "I co-operate with vertical partners to improve efficiency of goods delivery."

To measure innovation, the scale provided by Mendozaramírez and Toledolópez [34] was adopted. Specifically, the micro-entrepreneurs were asked to indicate the extent to which they agree or disagree with the statements, specifically they were asked to indicate the innovation implemented 
over the last three years. The items were, "I significantly improved size/shape/texture of the products," "Significantly improved finishing/color of the products," "Significantly improved quality of the products," "Modified technology/machinery/ tool/ equipment," "Used new technology in the production process," and "Developed new and unique designs which are different from our competitors."

Numerous indicators have been discussed in the literature to measure the performance of micro-enterprises. Most of the previous studies define firm performance from economic and/or financial perspective [71,72]. However, craft micro-entrepreneurs focus on success beyond mere economic measures which is contrary to other micro-enterprises, who give priority to financial success $[13,73]$. It has been argued that the craft micro-entrepreneurs also prefer the non-financial benefits [73]. Therefore, in this study, we have taken two indicators from each financial and non-financial success to measure the performance of craft micro-enterprises.

Consequently, the scales provided by Paige and Littrell [13] as well as by Tu, Hwang, and Wong [14] were adopted. Especially, the performance was measured with the following items: "In comparison to the first year of entrepreneurship, in the third year, current sales are higher," "I am satisfied with the current business development, as compared to the first year of entrepreneurship," "I am feeling satisfied with the profession," and "I am preserving and elevating the craft tradition."

All construct items were adopted from existing research, and all the items were measured using five-point Likert scales ranging from 1 (strongly disagree) to 5 (strongly agree). Particularly, the micro-entrepreneurs were asked to indicate the extent to which they agree or disagree with the statements.

\section{Results}

\subsection{Reliability and Validity}

Before conducting statistical analysis, the data was analyzed for outliers, missing data, linearity, and multicollinearity in order to avoid any bias or invalid result.

\subsubsection{Construct Validity}

We followed the guidelines proposed by Hair [74] to evaluate the construct validity. Consequently, the exploratory factor analysis (EFA) and confirmatory factor analysis (CFA) were employed. To assess the EFA, the commonly used assumptions were followed such as $\mathrm{KMO}>0.7$, the significance of Bartlett's test of sphericity, factor loadings $>0.5$, Eigenvalue $>1$, etc. In order to assess the CFA, the goodness of measurement model fit using structural equation modelling were followed, and all the model indices were within the threshold limit (Table 1).

The internal consistency was measured via Cronbach's alpha, and the value of the survey instrument is 0.828 , while the value for three constructs ranging from 0.762 to 0.911 , indicated an excellent internal consistency of the questionnaire. Moreover, the KMO value of each survey instrument ranging from 0.725 to 0.823 , and the statistically significant Bartlett's test of sphericity $(p<0.01)$, indicates the validity of the questionnaire is good.

The EFA result indicates that all vertical co-operation (VC) items, innovation (INNOV) items, and performance (PER) items loaded onto one factor. Further, the results of CFA of all constructs met the threshold limit of the goodness-of-fit indices indicating good convergent validity. The convergent validity was also assessed via composite reliability (CR) and average variance extracted (AVE), the results showed that each construct was within the acceptable limited of 0.7 and 0.5 respectively $[75,76]$. Furthermore, the standardized loading estimates of all the constructs were also within the threshold limit. Thus, the significant loadings and high value of CR and AVE indicate sufficient convergent validity of the scale. The results of EFA and CFA are shown in Table 1. 
Table 1. Exploratory and confirmatory factor analyses.

\begin{tabular}{|c|c|c|c|c|c|c|c|}
\hline \multirow[b]{2}{*}{ Construct } & \multirow[b]{2}{*}{ Item } & \multicolumn{3}{|c|}{ EFA Results } & \multicolumn{3}{|c|}{ CFA Results } \\
\hline & & $\begin{array}{c}\text { Factor } \\
\text { Loadings }\end{array}$ & KMO & $\begin{array}{l}\text { Explained } \\
\text { Variance }\end{array}$ & $\begin{array}{l}\text { Factor } \\
\text { Loadings }\end{array}$ & CR & AVE \\
\hline \multirow{7}{*}{$\begin{array}{c}\text { Vertical } \\
\text { co-operation } \\
\text { (VC) }\end{array}$} & VC1 & 0.766 & \multirow{6}{*}{0.823} & \multirow{6}{*}{$52.182 \%$} & 0.703 & \multirow{6}{*}{0.87} & \multirow{6}{*}{0.52} \\
\hline & VC2 & 0.655 & & & 0.557 & & \\
\hline & VC3 & 0.640 & & & 0.553 & & \\
\hline & VC4 & 0.791 & & & 0.762 & & \\
\hline & VC5 & 0.744 & & & 0.693 & & \\
\hline & VC6 & 0.726 & & & 0.637 & & \\
\hline & \multicolumn{7}{|c|}{$\begin{array}{l}\text { CFA model indices results, } \chi^{2}=13.902, p=0.126, \mathrm{NFI}=0.919, \mathrm{TLI}=0.948, \\
\mathrm{CFI}=0.969, \mathrm{GFI}=0.954, \mathrm{AGFI}=0.892, \mathrm{SRMR}=0.0479, \mathrm{RMSEA}=0.077\end{array}$} \\
\hline \multirow{7}{*}{$\begin{array}{l}\text { Innovation } \\
\text { (INNOV) }\end{array}$} & INNOV1 & 0.654 & \multirow{6}{*}{0.885} & \multirow{6}{*}{$72.010 \%$} & 0.596 & \multirow{6}{*}{0.94} & \multirow{6}{*}{0.72} \\
\hline & INNOV2 & 0.950 & & & 0.971 & & \\
\hline & INNOV3 & 0.949 & & & 0.974 & & \\
\hline & INNOV4 & 0.811 & & & 0.743 & & \\
\hline & INNOV5 & 0.902 & & & 0.874 & & \\
\hline & INNOV6 & 0.786 & & & 0.693 & & \\
\hline & \multicolumn{7}{|c|}{$\begin{array}{l}\text { CFA model indices results, } \chi^{2}=11.796, p=0.225, \mathrm{NFI}=0.977, \mathrm{TLI}=0.991, \\
\mathrm{CFI}=0.994, \mathrm{GFI}=0.959, \mathrm{AGFI}=0.904, \mathrm{SRMR}=0.0313, \mathrm{RMSEA}=0.058\end{array}$} \\
\hline \multirow{5}{*}{$\begin{array}{l}\text { Performance } \\
\text { (PER) }\end{array}$} & PER1 & 0.725 & \multirow{4}{*}{0.725} & \multirow{4}{*}{$60.193 \%$} & 0.589 & \multirow{4}{*}{0.85} & \multirow{4}{*}{0.60} \\
\hline & PER2 & 0.779 & & & 0.631 & & \\
\hline & PER3 & 0.670 & & & 0.537 & & \\
\hline & PER4 & 0.901 & & & 0.981 & & \\
\hline & \multicolumn{7}{|c|}{$\begin{array}{l}\text { CFA model indices results, } \chi^{2}=1.047, p=0.592, \mathrm{NFI}=0.991, \mathrm{TLI}=0.958 \\
\mathrm{CFI}=0.998, \mathrm{GFI}=0.995, \mathrm{AGFI}=0.973, \mathrm{SRMR}=0.0219, \mathrm{RMSEA}=0.013\end{array}$} \\
\hline
\end{tabular}

Finally, we assessed discriminant validity using the Fornell-Larcker criterion [77]. In this test, the square root of average variance extracted is compared with the correlation of the respective construct. The correlation analysis shows that square roots of all average variance extracted (ranging from 0.72 to 0.85 ) were more than the off-diagonal correlation (ranging from 0.272 to 0.357 ) for each corresponding construct. We also followed the approach of Ngo and O'Cass [78] to further validate the discriminant validity and found that the correlation between any two constructs was less than their respective composite reliability (ranging from 0.72 to 0.85 ). Overall, these findings suggest sufficient discriminant validity (Table 2).

Table 2. Descriptive statistics and construct level measurement statistics.

\begin{tabular}{|c|c|c|c|c|c|c|c|c|}
\hline & Mean & SD & $\begin{array}{c}\text { Cronbach's } \\
\text { Alpha }\end{array}$ & AVE & CR & 1 & 2 & 3 \\
\hline Vertical Co-operation & 4.19 & 0.687 & 0.803 & 0.52 & 0.87 & 0.72 & & \\
\hline Innovation & 4.36 & 0.665 & 0.911 & 0.72 & 0.94 & $0.309 * *$ & 0.85 & \\
\hline Performance & 4.42 & 0.559 & 0.762 & 0.60 & 0.85 & $0.272 * *$ & $0.357^{* *}$ & 0.77 \\
\hline
\end{tabular}

\subsubsection{Common Method Bias}

To control the common method bias, Harman's single-factor test was employed [79]. EFA with all variables present was run, and no single factor appeared to have more than $50 \%$ variance [79], the first factor only accounted for $30.697 \%$ of the total variance. Hence, the data should not be affected by common method variance. 


\subsection{Hypotheses Testing}

We used bootstrap re-sampling method to test our hypotheses, because this method has supremacy over others such as Baron and Kenny [80] and Sobel [81]. Moreover, this method is very popular among researchers. Recently, these both methods have been criticized because they both tests assume that the indirect effect $a b$ is normally distributed $[82,83]$. However, the distribution of $a b$ is recognized to be non-normal regardless of normally distributed ab product [84]. Thus, this notion raises concern, especially in a small sample size. Hence, we preferred the bootstrap re-sampling method. The simple mediator model (Model 4) in this study is tested using the SPSS macro PROCESS developed by Hayes [69], which includes both direct and indirect effects.

In Hypothesis 1, we proposed that the vertical co-operation (VC) is likely to affect innovation (INNOV), the results indicate that VC significantly and positively affects INNOV $(\beta=0.2992, p=0.0024)$ which supports our hypothesis, which means that co-operation with customers and suppliers leads to the innovation in textile crafts. The hypothesis $\mathrm{H} 2$ proposes that $\mathrm{VC}$ is likely to affect performance (PER), the results indicate that the total effect of VC on PER is significantly positive $(\beta=0.2213$, $p=0.0080$ ); thus, our hypothesis $\mathrm{H} 2$ is also supported. While the hypothesis $\mathrm{H} 3$ proposes that the INNOV is likely to affect PER, our results also support this hypothesis $(\beta=0.2535, p=0.0038)$.

Finally, the hypothesis H4 proposes that the INNOV acts as a mediator between VC and PER. To assess the mediating effect, the values of LLCI (lower level confidence interval) and ULCI (upper level confidence interval) should be evaluated in order to reject or accept the hypothesis. In case zero is contained in between these values with $95 \%$ confidence, it will lead to reject the hypothesis else the hypothesis will be accepted. As the confidence intervals do not contain the zero (0.0015 and 0.2783), the indirect mediating effect of innovation is significant which supports our hypothesis $\mathrm{H} 4$.

The overall evidence of the results suggested that vertical co-operation has a positive and significant impact on innovation and firm performance. Furthermore, the innovation also positively and significantly affected firm performance. In addition, we also find the significant mediating role of innovation between vertical co-operation and firm performance. Table 3 and Figure 2 indicates all the results.

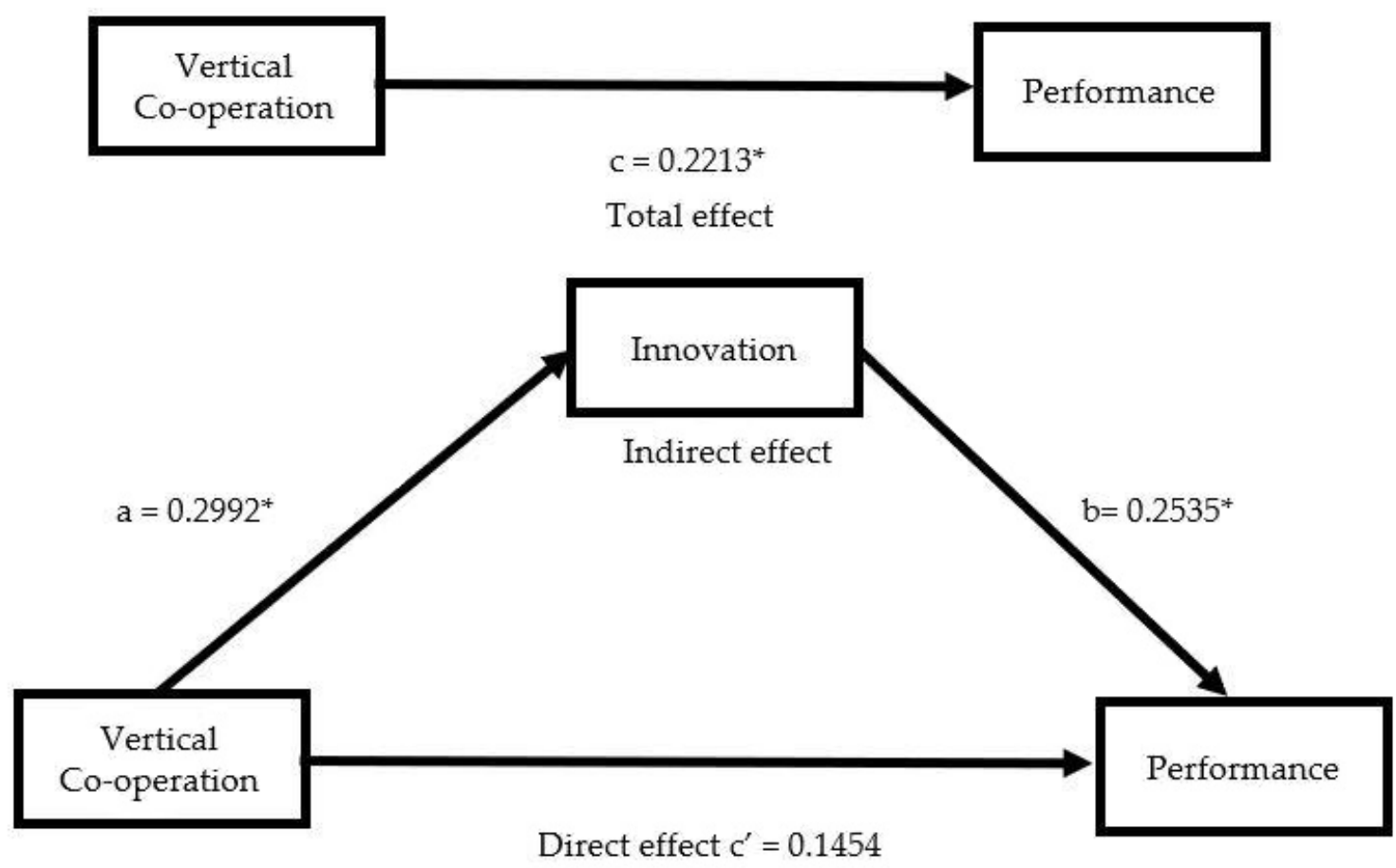

Figure 2. Regression results of simple mediator model. Notes: ${ }^{*} p<0.001$. 
Table 3. Regression results of simple mediation.

\begin{tabular}{ccccccc}
\hline Model & B & SE & $\mathbf{t}$ & $p$ & LLCI & ULCI \\
\hline VC $\rightarrow$ INNOV (path a) & 0.2992 & 0.0959 & 3.1214 & 0.0024 & 0.1088 & 0.4897 \\
INNOV $\rightarrow$ PER (path b) & 0.2535 & 0.0852 & 2.9742 & 0.0038 & 0.0842 & 0.4228 \\
VC $\rightarrow$ PER (path c) & 0.2213 & 0.0817 & 2.7100 & 0.0080 & 0.0591 & 0.3834 \\
VC $\rightarrow$ PER (path c') & 0.1454 & 0.0824 & 1.7642 & 0.0810 & -0.0183 & 0.3091 \\
$\quad$ Indirect effect & & & & & & 0.0015 \\
$\quad$ INNOV & 0.0759 & 0.0727 & & & 0.2783 \\
\hline
\end{tabular}

\section{Discussion}

The findings of our study indicate that vertical co-operation in textile crafts has a positive and significant effect on innovation which satisfies our Hypothesis H1. This finding is very important because innovation is not the sole domain of the craftsman rather involves certain partners [14,16,50,85]. Additionally, establishing vertical co-operation also help to share risk and uncertainty.

A further important result of this study is the significant and positive effect of innovation on firm performance which supports our Hypothesis H2. This is consistent with the studies of Chand, Southgate, and Naidu [12]; Tu, Hwang, and Wong [14]; and Rajapathirana and Hui [53]. This finding is also consistent with the study of Engel, Rothgang, and Trettin [56], who concluded that innovation has a positive impact on sales growth of small craft firms in Germany. Innovation is imperative for any firm $[40,86]$ which helps to improve firm performance; the textile craft micro-enterprises are without exception. Hence, in order to enable craft micro-enterprises to survive, compete and grow, innovation is one of the key factors to be considered [12,13,54].

The results further revealed a positive and significant effect of vertical co-operation on firm performance which satisfies our Hypothesis H3. This finding is consistent with the study of Ferraris, Santoro, and Bresciani [19], which suggests external knowledge positively and significantly affects the performance. In addition, Chen and Huang [65] also reported that the vertical co-operation with external agents directly affects the firm's performance. Thus, the vertical co-operative partners are very important to acquire external knowledge and resources for the improvement of firm performance, particularly, micro-enterprises.

Another interesting finding of the current study is the mediating role of innovation between vertical co-operation and firm performance. The results show the significant mediating effect of innovation; hence, Hypothesis 4 is accepted. This is the first study to replicate these findings in the context of micro-enterprises operating in the traditional sector, particularly, textile crafts.

\section{Conclusions}

Although the creative micro-enterprises in the craft sector provide income and employment generation to a large number of poor people. However, these micro-enterprises face resources constraints. Hence, this study was aimed to examine the role of vertical co-operation in improving the performance of creative micro-enterprises in textile crafts through innovation. The findings indicate that the vertical co-operation improves the innovation and thereby performance of such micro-enterprises.

Our study indicates that vertical co-operation can help these enterprises to innovate and exploit their products in the market successfully. Further, the findings of our research also provide useful insights into the role of vertical co-operation to improve performance, in addition to fostering innovation. Vertical co-operation enables these micro-enterprises to acquire resources, information, and knowledge that help the entrepreneurs to produce sustainable products. Moreover, the vertical co-operation not only increase the chances of acceptance of innovated products but also the feedback of buyers is very helpful to make necessary modifications in the products in order to differentiate handicrafts than those mass produced and compete in the market [6]. Thus, micro-entrepreneurs involved in these businesses should make long term relations with their vertical partners in order 
to access resources to survive and compete in the market [14]. This study argues that a creative micro-enterprise needs to strengthen its vertical relations in order to access low-cost resources to successfully exploit innovation in the market, which will lead to higher firm performance $[9,25,45]$.

Contrary to some studies that raise concern over innovation in crafts because it involves traditional skills and knowledge $[26,28]$, our study empirically provided evidence regarding innovation in crafts in terms of product improvements (design, size, shape, color, etc.), quality improvements, and replacement/ modification of tools. The textile crafts are closely related to the fashion industry; hence, many consumers may not like the old designs [25], and thus the innovation, without killing the traditional motif, attracts the consumers. The findings further indicate that innovation plays a mediating role between vertical co-operation and firm performance. All hypotheses were tested using SPSS macro PROCESS developed by Hayes [69].

We infer from the results that textile craft micro-enterprises acquire valuable information from vertical counterparts. However, for them to improve their performance the mediating effect of innovation is essential. These results are in line with previous studies that have focused on co-operative innovation in micro firms (for instance Tu, Hwang and Wong [14]).

\subsection{Implications}

The current research focuses on creative micro-enterprises in textile craft sector because these enterprises have received very little attention from academia research, especially with respect to vertical co-operation and innovation. Particularly, this paper fulfills an identified need to study how vertical co-operation improves the performance of micro-enterprises in textile crafts through innovation. Moreover, this is a pioneering study that examined the relationship between vertical co-operation, innovation, and performance in the context of creative micro-enterprises in textile crafts.

Although several studies have been conducted on co-operation, collaboration, marketing networks, and co-operative ties in the handicraft industry $[16,25,26,31]$, none of these studies explored the mediating effect of innovation between vertical co-operation and performance in the context of handicraft micro-enterprises, particularly in textile crafts, thus this study can be used as a reference in future studies. Further, most of the studies conducted on co-operation in general in the handicraft industry are qualitative nature $[25,26]$, and this study is the first of its kind in the context of textile crafts in Pakistan.

The contribution of this study is related to measurement and empirically providing evidence regarding innovation in crafts. Although innovation in micro-firms has been studied widely, in the context of crafts, it raises concern over the authenticity of innovation due to the involvement of traditional skills and knowledge [26,28]. However, the findings of this study empirically prove that the micro-enterprises in craft sector involve innovation in terms of product improvements (design, size, shape, color, etc.), quality improvements, and replacement/modification of tools. Hence, the micro-entrepreneurs in textile crafts should adopt cooperative strategies that stimulate innovation in order to survive in the market.

In addition, unlike previous related studies, that have used dichotomous/binary variables to measure cooperation and innovation behaviors (such as $[12,17,87,88]$ ), this study used primary data that captures the cooperation and innovation behavior through the questionnaire. Such data is necessary to explore the relationship between vertical co-operation, innovation, and performance which is very mandatory to maintain the external relations and enhance business performance, especially in the context of micro-enterprise.

Furthermore, for practitioners and policymakers, several suggestions are provided according to the research results. The micro-enterprises need to establish long term mutually beneficial relationships with vertical partners to boost innovation opportunities. For instance, the customers and suppliers may help micro-enterprises to successfully innovate and exploit the products in the market for sustainable development. Thus, the creative micro-enterprises in textile craft sector intending to improve their business performance are suggested to focus on innovation in order to survive in the market. 
In view of the cultural and economic importance of creative micro-enterprise, the stakeholders and policymakers may consider the findings of our study to stimulate a stable growth of micro-enterprises in the crafts sector in Pakistan. It is recommended to create awareness among the creative micro-entrepreneurs in the craft sector about the benefits of vertical co-operation in order to access business and market information and other resources necessary to improve their business performance.

Our study also reveals that most of the micro-entrepreneurs are middle-aged (41-50 years, $62.8 \%$ ), which indicates that the young generation may be unwilling to pursue this career. Thus, the Government should pay more attention to encourage the young generation to pursue this career [6].

\subsection{Limitations}

Despite our interesting results and contributions, the study is not without limitations which provide room for future research. First, the limited number of observations does not support the broader generalization of its implications; hence, further studies are suggested to reconfirm the findings of the current study by incorporating a large number of samples. Moreover, because the respondents were textile craft micro-entrepreneurs, hence, the generalizability of results to other craft sectors is restricted. Accordingly, further studies are recommended to cover other sectors in the handicraft industry. Another limitation of the current study is the location of sampled micro-enterprises, District Matiari of Sindh Province Pakistan; hence, the readers must be cautious in generalizing the results of our study to micro-enterprises functioning outside the geographical area. Thus, it provides room for future studies to investigate the proposed relationships between studied variables using data from different regions. Future studies can also examine the effect of external co-operation on innovation and performance by drawing representative sample from multiple subsectors of craft industry, especially from developing economies where such studies are rare, and most of the handicraft micro-enterprises live a precarious life $[6,10]$.

Although the findings of our study indicate the important role of vertical co-operative partners in innovation and improving firm performance, the study does not indicate which co-operative partner has the greatest influence on innovation. Furthermore, in this study, we did not deeply examine the innovation in crafts. However, various studies indicate that handicrafts involve product as well as process innovations [34,57]; thus, it would be interesting to examine the individual effect of each partner on the product as well as process innovations.

Author Contributions: M.S. conceptualized and designed the study and wrote the paper; Y.Y. revised and improved the quality of the manuscript; Z.K. and A.Y. contributed in revision and final editing.

Funding: We gratefully acknowledge the research funding received from the Key Project of the National Social Science Fund (18AGL024).

Conflicts of Interest: The authors declare no conflict of interest.

\section{References}

1. Allal, M.; Chuta, E. Cottage Industries and Handicrafts; Some Guidelines for Employment Promotion; International Labor Organization: Genève, Switzerland, 1982; ISBN 9221030296.

2. Richard, N. Handicrafts and Employment Generation for the Poorest Youth and Women; United Nations Educational, Scientific and Cultural Organization UNESCO: Paris, France, 2007.

3. Jones, E.; Smith, S.; Wills, C. Women producers and the benefits of collective forms of enterprise. Gend. Dev. 2012, 20, 13-32. [CrossRef]

4. Fatt, B.S.; Bakansing, S.M. An alternative raw material in handicraft-making by using the oil palm fronds: A community based tourism exploratory study at Kota Belud, Sabah. Tour. Leis. Glob. Chang. 2016, 1, 25-37.

5. Abisuga-Oyekunle, O.A.; Fillis, I.R. The role of handicraft micro-enterprises as a catalyst for youth employment. Creat. Ind. J. 2017, 10, 59-74. [CrossRef]

6. Yang, Y.; Shafi, M.; Song, X.; Yang, R. Preservation of cultural heritage embodied in traditional crafts in the developing countries. A case study of Pakistani handicraft industry. Sustainability 2018, 10, 1336. [CrossRef] 
7. DCMS (Department for Culture Media and Sport). Creative Industries Mapping Document; DCMS London: London, UK, 1998.

8. Mueller, J.; Abecassis-Moedas, C. Factors influencing the integration of external evaluations in the open innovation process: A qualitative study in micro-firms in the creative industries. J. Strategy Manag. 2017, 10, 248-260. [CrossRef]

9. Gundolf, K.; Jaouen, A.; Gast, J. Motives for strategic alliances in cultural and creative industries. Creat. Innov. Manag. 2018, 27, 148-160. [CrossRef]

10. Scrase, T.J. Precarious production: Globalisation and artisan labour in the third world. Third World Q. 2003, 24, 449-461. [CrossRef]

11. Grobar, L.M. Policies to promote employment and preserve cultural heritage in the handicraft sector. Int. J. Cult. Policy 2017, 1-13. [CrossRef]

12. Chand, A.; Southgate, P.; Naidu, S. Determinants of innovation in the handicraft industry of Fiji and Tonga: An empirical analysis from a tourism perspective. J. Enterp. Communities People Places Glob. Econ. 2014, 8, 318-330.

13. Paige, R.C.; Littrell, M.A. Craft retailers' criteria for success and associated business strategies. J. Small Bus. Manag. 2002, 40, 314-331. [CrossRef]

14. Tu, C.; Hwang, S.N.; Wong, J.Y. How does cooperation affect innovation in micro-enterprises? Manag. Decis. 2014, 52, 1390-1409. [CrossRef]

15. Tomlinson, P.R. Co-operative ties and innovation: Some new evidence for UK manufacturing. Res. Policy 2010, 39, 762-775. [CrossRef]

16. Jackson, I.; Tomlinson, P.R. The role of cooperation in a creative industry: The case of UK studio pottery. Int. Rev. Appl. Econ. 2009, 23, 691-708. [CrossRef]

17. Propris, L.D. Innovation and inter-firm co-operation. Entrep. Reg. Dev. 2002, 14, 337-353. [CrossRef]

18. Martin-Rios, C.; Erhardt, N. Small business activity and knowledge exchange in informal interfirm networks. Int. Small Bus. J. 2017, 35, 285-305. [CrossRef]

19. Ferraris, A.; Santoro, G.; Bresciani, S. Open innovation in multinational companies' subsidiaries: The role of internal and external knowledge. Eur. J. Int. Manag. 2017, 11, 452-468. [CrossRef]

20. Van Gils, A.; Zwart, P.S. Alliance formation motives in smes: An explorative conjoint analysis study. Int. Small Bus. J. 2009, 27, 5-37. [CrossRef]

21. Ulrich, D. Governing transactions: A framework for cooperative strategy. Hum. Resour. Manag. 1983, 22, 23-39. [CrossRef]

22. Chesbrough, H. Open Innovation: Researching a New Paradigm; Oxford University Press: Oxford, UK, 2006.

23. Harabi, N. Innovation through vertical relations between firms, suppliers and customers: A study of German firms. Ind. Innov. 1998, 5, 157-179. [CrossRef]

24. Jaklič, A.; Damijan, J.P.; Rojec, M.; Kunčič, A. Relevance of innovation cooperation for firms' innovation activity: The case of Slovenia. Econ. Res.-Ekonomska Istraživanja 2014, 27, 645-661. [CrossRef]

25. Torres, A.M. Marketing networks as a form of strategic alliance among craft enterprises. Int. J. Nonprofit Volunt. Sect. Mark. 2002, 7, 229-243. [CrossRef]

26. Duarte Alonso, A.; Bressan, A. Collaboration in the context of micro businesses: The case of terracotta artisans in Impruneta (Italy). Eur. Bus. Rev. 2014, 26, 254-270. [CrossRef]

27. Jaouen, A.; Gundolf, K. Strategic alliances between microfirms: Specific patterns in the French context. Int. J. Entrep. Behav. Res. 2009, 15, 48-70. [CrossRef]

28. Zhan, X.; Walker, S.; Hernandezpardo, R.; Evans, M. Craft and sustainability: Potential for design intervention in crafts in the Yangtze River Delta, China. Des. J. 2017, 20, S2919-S2934. [CrossRef]

29. Organisation for Economic Co-Operation and Development. The Measurement of Scientific and Technological Activities: Guidelines for Collecting and Interpreting Innovation Data; OECD: Paris, France, 2005.

30. Wadho, W.; Chaudhry, A. Innovation and firm performance in developing countries: The case of Pakistani textile and apparel manufacturers. Res. Policy 2018, 47, 1283-1294. [CrossRef]

31. Tomlinson, P.R.; Jackson, I. Cooperative ties and the impact of external factors upon innovation in an industrial district: Some insights from the north staffordshire table and giftware sector. Reg. Stud. 2013, 47, 580-596. [CrossRef]

32. Zeng, S.X.; Xie, X.M.; Tam, C.M. Relationship between cooperation networks and innovation performance of SMEs. Technovation 2010, 30, 181-194. [CrossRef] 
33. Parida, V.; Westerberg, M.; Frishammar, J. Inbound open innovation activities in high-tech SMEs: The impact on innovation performance. J. Small Bus. Manag. 2012, 50, 283-309. [CrossRef]

34. Mendozaramírez, L.; Toledolópez, A. Strategic orientation in handicraft subsistence businesses in Oaxaca, Mexico. J. Mark. Manag. 2014, 30, 476-500. [CrossRef]

35. UNESCO. Designers Meet Artisans: A Practical Guide. Available online: http://unesdoc.unesco.org/ images /0014/001471/147132EO.pdf (accessed on 24 September 2018).

36. Ahluwalia, S.; Mahto, R.V.; Walsh, S.T. Innovation in small firms: Does family vs. Non-family matter? J. Small Bus. Strategy 2017, 27, 39-49.

37. Evans, K.; Stockley, S.; Taylor, C.; Brown, J.; Rab, M.; Khan, S. Cultural and Creative Industries in Pakistan; British Council: Islamabad, Pakistan, 2014.

38. Zahra, S. Virsa: The Contemporary Value Chain. Master's Thesis, Virginia Commonwealth University, Richmond, VA, USA, 2015.

39. Goldsby, M.G.; Kreiser, P.M.; Kuratko, D.F.; Bishop, J.W.; Kreiser, P.M.; Hornsby, J.S. Social proactiveness and innovation: The impact of stakeholder salience on corporate entrepreneurship. J. Small Bus. Strategy 2018, 28, $1-15$.

40. Lee, S.M.; Trimi, S. Innovation for creating a smart future. J. Innov. Knowl. 2018, 3, 1-8. [CrossRef]

41. Tacer, B.; Mitja, R.; Tine, N. User-driven innovation: Scale development and validation au-Tacer, blanka. Econ. Res.-Ekonomska Istraživanja 2018, 31, 1472-1487. [CrossRef]

42. Grant, R.M. Toward a knowledge-based theory of the firm. Strateg. Manag. J. 1996, 17, 109-122. [CrossRef]

43. Morris, M.H.; Kocak, A.; Ozer, A. Coopetition as a small business strategy: Implications for performance. J. Small Bus. Strategy 2007, 35-56.

44. Barnir, A.; Smith, K.A. Interfirm alliances in the small business: The role of social networks. J. Small Bus. Manag. 2002, 40, 219-232.

45. Tsai, K.-H. Collaborative networks and product innovation performance: Toward a contingency perspective. Res. Policy 2009, 38, 765-778. [CrossRef]

46. Tsai, K.H.; Tsai, M.L.; Wang, J.C. Supplier collaboration and new product performance: A contingency model. Ind. Manag. Data Syst. 2012, 112, 268-289. [CrossRef]

47. Scott, A.J. The craft, fashion, and cultural-products industries of los angeles: Competitive dynamics and policy dilemmas in a multisectoral image-producing complex. Ann. Assoc. Am. Geogr. 1996, 86, 306-323. [CrossRef]

48. Löfqvist, L. Motivation for innovation in small enterprises. Int. J. Technol. Manag. 2012, 60, $242-265$. [CrossRef]

49. Von Hippel, E. Appropriability of innovation benefit as a predictor of the source of innovation. Res. Policy 1982, 11, 95-115. [CrossRef]

50. Geroski, P.A. Vertical relations between firms and industrial policy. Econ. J. 1992, 102, 138-147. [CrossRef]

51. Tether, B.S. Who co-operates for innovation, and why: An empirical analysis. Res. Policy 2002, 31, 947-967. [CrossRef]

52. Smallbone, D.; North, D. Innovation and new technology in rural small and medium-sized enterprises: Some policy issues. Environ. Plan. C Gov. Policy 1999, 17, 549-566. [CrossRef]

53. Rajapathirana, R.P.J.; Hui, Y. Relationship between innovation capability, innovation type, and firm performance. J. Innov. Knowl. 2018, 3, 44-55. [CrossRef]

54. Paige, R.C. Profiles of successful craft micro-retailors. J. Dev. Entrep. 2009, 14, 393-412.

55. Roper, S.; Hewitt-Dundas, N. Investigating a neglected part of schumpeter's creative army: What drives new-to-the-market innovation in micro-enterprises? Small Bus. Econ. 2017, 49, 559-577. [CrossRef]

56. Engel, D.; Rothgang, M.; Trettin, L. Innovation and their impact on growth of SME-Empirical evidence from craft dominated industries in Germany. In Proceedings of the EARIE 2004 Conference, Berlin, Germany, 2-5 September 2004; pp. 2-5.

57. Sánchezmedina, P.S.; Corbett, J.; Toledolópez, A. Environmental innovation and sustainability in small handicraft businesses in Mexico. Sustainability 2011, 3, 984-1002. [CrossRef]

58. Radicic, D.; Pugh, G. Performance effects of external search strategies in european small and medium-sized enterprises. J. Small Bus. Manag. 2017, 55, 76-114. [CrossRef]

59. Molina, A.; Aranda, E.; Martín, V.J.; Santos, J. Opportunities for craft consumption: Analysis of the quality perceived by consumers. Int. J. Glob. Small Bus. 2014, 6, 64-78. [CrossRef] 
60. Moran, P. Structural vs. Relational embeddedness: Social capital and managerial performance. Strateg. Manag. J. 2005, 26, 1129-1151. [CrossRef]

61. Freeman, S.; Hutchings, K.; Lazaris, M.; Zyngier, S. A model of rapid knowledge development: The smaller born-global firm. Int. Bus. Rev. 2010, 19, 70-84. [CrossRef]

62. Barney, J. Firm resources and sustained competitive advantage. J. Manag. 1991, 17, 99-120. [CrossRef]

63. Barney, J.B. Resource-based theories of competitive advantage: A ten-year retrospective on the resource-based view. J. Manag. 2001, 27, 643-650. [CrossRef]

64. Saenz, J.; Pérez-Bouvier, A. Interaction with external agents, innovation networks, and innovation capability: The case of uruguayan software firms. J. Knowl. Manag. 2014, 18, 447-468. [CrossRef]

65. Chen, C.-J.; Huang, J.-W. Strategic human resource practices and innovation performance-The mediating role of knowledge management capacity. J. Bus. Res. 2009, 62, 104-114. [CrossRef]

66. Hassan, T.M.R.T.; Yaacob, M.R.; Abdullatiff, N.K. Sustaining smes wood-based product manufacturing through best practices-The case of indigenous entrepreneurs in Kelantan. Procedia Soc. Behav. Sci. 2014, 115, 221-234. [CrossRef]

67. Saunila, M.; Pekkola, S.; Ukko, J. The relationship between innovation capability and performance. Int. J. Product. Perform. Manag. 2014, 63, 234-249. [CrossRef]

68. Weber, B.; Heidenreich, S. When and with whom to cooperate? Investigating effects of cooperation stage and type on innovation capabilities and success. Long Range Plan. 2018, 51, 334-350. [CrossRef]

69. Hayes, A.F. Introduction to Mediation, Moderation, and Conditional Process Analysis: A Regression-Based Approach; The Guilford Press: New York, NY, USA, 2013.

70. Pustovrh, A.; Jaklič, M.; Martin, S.A.; Rašković, M. Antecedents and determinants of high-tech smes' commercialisation enablers: Opening the black box of open innovation practices au-Pustovrh, aleš. Econ. Res.-Ekonomska Istraživanja 2017, 30, 1033-1056. [CrossRef]

71. Masuo, D.; Fong, G.; Yanagida, J.; Cabal, C. Factors associated with business and family success: A comparison of single manager and dual manager family business households. J. Fam. Econ. Issues 2001, 22, 55-73. [CrossRef]

72. Gatewood, E.J.; Shaver, K.G.; Gartner, W.B. A longitudinal study of cognitive factors influencing start-up behaviors and success at venture creation. J. Bus. Ventur. 1995, 10, 371-391. [CrossRef]

73. Paige, R.C. Craft Retail Entrepreneurs' Perceptions of Success and Factors Affecting Success. Ph.D. Thesis, IOWA State University, Ames, IA, USA, 1999.

74. Hair, G.B.; Babin, B.; Anderson, R.; Tatham, R. Multivariate Data Analysis, 7th ed.; Pearson: Upper Saddle River, NJ, USA, 2010.

75. Bagozzi, R.P.; Yi, Y. On the evaluation of structural equation models. J. Acad. Mark. Sci. 1988, 16, 74-94. [CrossRef]

76. Hair, J.F.; Hult, G.T.M.; Ringle, C.M.; Sarstedt, M. A Primer on Partial Least Squares Structural Equation Modeling (PLS-SEM); Sage: Thousand Oaks, CA, USA, 2014.

77. Fornell, C.; Larcker, D.F. Evaluating structural equation models with unobservable variables and measurement error. J. Mark. Res. 1981, 18, 39-50. [CrossRef]

78. Ngo, L.V.; O'Cass, A. In search of innovation and customer-related performance superiority: The role of market orientation, marketing capability, and innovation capability interactions. J. Prod. Innov. Manag. 2012, 29, 861-877. [CrossRef]

79. Podsakoff, P.M.; Mackenzie, S.B. Common method biases in behavioral research: A critical review of the literature and recommended remedies. J. Appl. Psychol. 2003, 88, 879-903. [CrossRef]

80. Baron, R.M.; Kenny, D.A. The moderator-mediator variable distinction in social psychological research: Conceptual, strategic, and statistical considerations. J. Personal. Soc. Psychol. 1986, 51, 1173. [CrossRef]

81. Sobel, M.E. Asymptotic confidence intervals for indirect effects in structural equation models. Sociol. Methodol. 1982, 13, 290-312. [CrossRef]

82. MacKinnon, D.P.; Lockwood, C.M.; Hoffman, J.M.; West, S.G.; Sheets, V. A comparison of methods to test mediation and other intervening variable effects. Psychol. Methods 2002, 7, 83-104. [CrossRef]

83. Preacher, K.J.; Hayes, A.F. Spss and sas procedures for estimating indirect effects in simple mediation models. Behav. Res. Methods Instrum. Comput. 2004, 36, 717-731. [CrossRef]

84. Edwards, J.R.; Lambert, L.S. Methods for integrating moderation and mediation: A general analytical framework using moderated path analysis. Psychol. Methods 2007, 12, 1-22. [CrossRef] [PubMed] 
85. Love, J.H.; Mansury, M.A. External linkages, R\&D and innovation performance in us business services. Ind. Innov. 2007, 14, 477-496.

86. Yang, Y. An Introduction to Creative Management; Economy and Management Publishing House: Hong Kong, China, 2018.

87. Freel, M.S.; Harrison, R.T. Innovation and cooperation in the small firm sector: Evidence from 'Northern Britain'. Reg. Stud. 2006, 40, 289-305. [CrossRef]

88. Rodriguez, M.; Doloreux, D.; Shearmur, R. Variety in external knowledge sourcing and innovation novelty: Evidence from the KIBS sector in Spain. Technovation 2017, 68, 35-43. [CrossRef]

(C) 2019 by the authors. Licensee MDPI, Basel, Switzerland. This article is an open access article distributed under the terms and conditions of the Creative Commons Attribution (CC BY) license (http:/ / creativecommons.org/licenses/by/4.0/). 